\title{
FENOMENA POLIGAMI ANTARA SOLUSI SOSIAL DAN WISATA SEKSUAL DALAM ANALISIS HUKUM ISLAM, UU NO. 1 TAHUN 1974, DAN KHI
}

\begin{abstract}
Moh. Faizur Rohman \& Muhammad Solikhudin
Fakultas Syari'ah dan Hukum UIN Sunan Ampel Surabaya. Email: faza_veiro@yahoo.co.id \& udin_gezwa@yahoo.co.id

Abstract: Polygamy is one of the most talked-about and controversial issues of marriage. It is rejected in a variety of arguments such as normatively and psychologicaly. Even, it is always associated with a gender inequality as expressed by some of the gender activists or women activists. Western writers often claim that polygamy is evidence that the teaching of Islam in the field of marriage is very discriminatory against women. On the other hand, polygamy is campaigned because it is considered as an alternative to solve the phenomenon of cheating and prostitution. Whatever the reasons expressed, polygamy is clearly mentioned in the Qur'an, regardless of how the verse is applied. The problem is in what conditions and by whom the concept of polygamy can be implemented. This paper will investigate the polygamy as the simultaneous social solusion and sexual tour. To answer to questions of the research, the author will use Law No. 1 Year 1974, and Islamic Law Compilation (KHI) as a blade analysis. To get more comprehensive discussion, writer will also use the phenomenological approach.
\end{abstract}

Keywords: Polygamy, Islamic Law, Positive Law, Phenomenology.

Abstrak: Poligami merupakan salah satu persoalan dalam perkawinan yang paling banyak dibicarakan sekaligus kontroversial. Satu sisi poligami ditolak dengan berbagai macam argumentasi, baik yang bersifat normatif, psikologis, bahkan selalu dikaitkan dengan ketidakadilan gendersebagaimana diungkapkan aktivis gender atau pegiat perempuan. Bahkan penulis Barat sering mengklaim, bahwa poligami adalah bukti, bahwa ajaran Islam dalam bidang perkawinan sangat diskriminatif terhadap perempuan. Pada sisi lain, poligami dikampanyekan karena dianggap sebagai salah satu alternatif untuk menyelesaikan fenomena selingkuh dan prostitusi. Apapun alasan yang diungkapkan, yang jelas poligami merupakan shari'ah agama yang keberadaannya jelas di dalam al-Qur'an, terlepas bagaimana ayat tersebut diterapkan. Permasalahannya adalah dalam kondisi yang bagaimana dan oleh siapa shari'ah poligami ini bisa dilaksanakan. Tulisan ini mencoba mengkaji poligami yang pada satu sisi berdampak pada solusi sosial, pada sisi yang lain bisa dianggap sebagai wisata seksual yang dilakukan suami, dan bisa juga kedua alasan tersebut 
Moh. Faizur Rohman \& Muhammad Solikhudin: Fenomena Poligami...

berkelindan secara bersamaan. Selanjutnya penulis membahas poligami tersebut dengan pisau analisis Hukum Islam, UU No. 1 Tahun 1974, dan KHI (Hukum Positif). Tidak hanya itu, penulis juga berupaya merelevansikan kajian poligami ini dengan pisau analisis teori fenomenologi dalam ilmu sosiologi.

Kata Kunci: Poligami, Hukum Islam, Hukum Positif, Fenomenologi.

\section{Pendahuluan}

Tidak ada yang paling membahagiakan di dunia ini, kecuali jika seseorang telah menemukan tambatan hatinya untuk dipersunting sebagai pendamping hidup dan bersama-sama membangun mahligai rumah tangga yang bahagia, kekal penuh dengan rasa cinta dan kasih sayang. Seorang laki-laki tidak pantas terus-menerus membujang, sementara ia telah memiliki kemampuan secara ekonomi maupun secara biologis, kemantapan lahiriah dan batiniah. Demikian pula, seorang wanita, hendaknya tidak menunda-nunda perkawinan karena usia semakin tua bukan semakin baik untuk melahirkan keturunan. ${ }^{1}$

Agama Islam memulai pembentukan keluarga dari sebuah ikatan kuat yang disebut pernikahan. ${ }^{2}$ Pernikahan inilah yang menjadi awal dari segala dialektika kehidupan dalam berumah tangga. Oleh karena itulah telah dijelaskan dalam al-Qur'an dan alSunnah tentang banyak teks yang menyebutkan dan menjelaskan persoalan-persoalan terkait pernikahan, baik pra nikah, ketika

${ }^{1}$ Beni Ahmad Saebani, Fiqh Munakhat (Bandung: Pustaka Setia,2009), 5.

2 'Perkawinan menurut shara' yaitu akad yang ditetapkan syara' untuk membolehkan bersenang-senang antara laki-laki dengan perempuan dan menghalalkan bersenang-senangnya perempuan dengan laki-laki”. Lihat Wahbah Al- Zuhaily, Al- Figh Al-Islami wa Adillatubu, (Damaskus: Dar Al- Fikr, 1997), 614. Didalam kitab Mughni al-Mubtäj dijelaskan bahwa Pernikahan menurut etimologi memiliki arti menghimpit, menindih atau berkumpul. Sedangkan arti majasnya adalah wata' yang mempunyai arti bersetubuh atau aqad yang berarti mengadakan perjanjian. Lihat Syamsudin Muhammad ibn Muhammad al-Khatib al-Syarbini, Mughnì al-Mubtäj (Bairut: Dar al-Kutub al-Islamiyah, 1994), Jilid IV, 200. Namun, menurut pendapat yang shahih, nikah arti hakikatnya adalah akad. Sedangkan wati i' sebagai arti majasnya. Lihat Abdullah ibn Hijazi ibn Ibrahim alSyafi'i al-Azhary, Hāsyiah al-Syarqāwì (Bairut: Dar al-Kutub al-Ilmiah,2005), Juz II, 242.

\begin{tabular}{l|l} 
AL-HUKAMA \\
The Indonesian Journal of Islamic Family Law \\
Volume 07, Nomor 01, Juni 2017
\end{tabular} 
pernikahan sudah berlangsung, ataupun pada paska nikah (ketika terjadi perceraian). Hal ini menunjukkan bahwa persoalan pernikahan bukanlah hal yang main-main dan bersifat kebutuhan seksual sementara belaka, tapi lebih dari itu, pernikahan merupakan suatu ikatan yang sangat kuat (misiäqan gholì̧han) untuk terciptanya kehidupan rumah tangga yang harmonis, sakinah, mawaddab wa rahmah. Allah SWT berfirman dalam surat Ar-Rumm (30):21:

Dan diantara tanda-tanda kekuasaan-Nya ialah dia menciptakan untukmu istri-istri dari jenismu sendiri, supaya kamu cenderung dan merasa tentram kepadanya, dan dijadikannya diantaramu rasa kasih sayang, sesunggubnya pada yang demikian itu benar-benar terdapat tanda-tanda bagi kaum yang berfikir. ${ }^{3}$

Salah satu persoalan penting yang sering dijadikan tuduhan bahwa Islam menganiaya perempuan dan berpihak pada lelaki secara mutlak ialah masalah poligami, yakni diizinkannya lelaki mengumpulkan lebih dari satu isteri.Poligami merupakan salah satu tema penting khusus dari Allah SWT. sehingga tidak mengherankan kalau Allah meletakkannya pada surat An-Nisa' dalam kitab-Nya yang mulia. Poligami terjadi ketika seorang lakilaki yang telah memiliki istri menikah lagi dengan perempuan lain. Dalam islam, sudah menjadi pengetahuan umum bahwa seseorang laki-laki diperbolehkan menikahi beberapa perempuan hingga empat orang.

Meskipun dalam Islam ada kebolehan untuk melakukan poligami, namun jika tidak bisa untuk berlaku adil maka diwajibkan untuk menikahi satu orang istri saja. Persyaratan "keadilan" inilah yang masih dikesampingkan oleh banyak orang. Untuk itu lahirlah Undang-Undang No. 1 Tahun 1974 tentang Perkawinan sebagai bentuk respon yang positif untuk mengatur seorang suami yang ingin menikah lebih dari satu orang, tentunya dengan berdasarkan pada ketentuan-ketentuan yang harus dipenuhi. Demikian juga lahirlah Kompilasi Hukum Islam yang mengatur ketentuan poligami yang lebih condong pada agama Islam.

3 Departemen Agama RI, Al-Qur'an al-Karim dan Terjemahnya (Kudus: Menara Kudus $1427 \mathrm{H}), 406$. 
Undang-Undang No. 1 Tahun 1974 tentang Perkawinan dan KHI ini bertujuan memberikan ketentuan berupa persyaratan bagi suami yang hendak menikah lagi sehingga tertutuplah sikap semena-mena dari pihak suami. Hal ini juga demi terciptanya keluarga yang sakinah, mawaddah dan rahmah. Tentunya dengan dilakukannya poligami ini akan ada hikmah yang terkandung didalamnya jika dilandasi oleh rasa keadilan. Jika tidak dilandasi oleh rasa keadilan, petaka yang nantinya akan timbul dalam rumah tangga.

Tulisan ini mencoba mengkaji poligami sebagai solusi sosial pada satu sisi dan pada sisi yang lain bisa dianggap sebagai wisata seksual yang dilakukan suami.Bisa juga kedua alasan tersebut berkelindan secara bersamaan. Selanjutnya penulis membahaspoligami tersebut dengan pisau analisis Hukum Islam, Undang-Undang No. 1 Tahun 1974 tentang Perkawinan, dan KHI. Tidak hanya itu, penulis juga berupaya merelevansikan kajian poligami ini dengan pisau analisis teori fenomenologi dalam ilmu sosiologi.

\section{Pernikahan dan Poligami}

Dalam bahasa Indonesia, perkawinan berasal dari kata "kawin" yang menurut bahasa artinya membentuk keluarga dengan lawan jenis; melakukan hubungan kelamin atau bersetubuh. Perkawinan disebut juga "pernikahan", berasal dari kata nikäh yang menurut bahasa artinya mengumpulkan, saling memasukkan, dan digunakan untuk arti bersetubuh (waț). Kata "nikeäh" sendiri sering dipergunakan untuk arti persetubuhan (coitus), juga untuk arti akad nikah. ${ }^{4}$ Kata perkawinan jika disandarkan pada pembatasan usia, maka arti yang dirasakan lebih sesuai adalah "akad nikäh". Sedangkan menurut Wahbah Zuhaili, pernikahan secara terminologi adalah:

${ }^{4}$ Abdul Rahman Ghozali, Figh Munakahat, Cet. Ke-III (Jakarta: Kencana,2008), 7.

4 \begin{tabular}{l|l} 
AL-HUKAMA \\
The Indonesian Journal of Islamic Family Law \\
Volume 07, Nomor 01, Juni 2017
\end{tabular} 
"Perkawinan menurut syara' yaitu akad yang ditetapakan syara' untuk membolebkan bersenang-senang antara laki-laki dengan perempuan dan menghalalkan bersenang-senangnya perempuan dengan laki-laki, ${ }^{5}$

Demikian juga disebutkan di dalam kitab al-Fiqh 'ala Mażabib al-Arba'ah oleh Abdurrahman al-Jaziri bahwa kata "perkawinan" atau nikah secara etimologi adalah wati'a yang berarti bersenggama atau bercampur. Dalam pengertian majas, orang menyebut nikah sebagai aqad, yang aqad tersebut menyebabkan diperbolehkan senggama.6

Nikah dalam arti wati'a (senggama) sebagaimana firman Allah SWT dalam QS. al-Baqarah (2): 230:

"Kemudian si suami mentalaknya (sesudah talak yang kedua) maka perempuan itu tidak halal lagi baginya hingga dia kawin dengan suami yang lain...".7

Nikah berarti akad terdapat dalam firman Allah yaitu QS. alNur (24): 32:

"Dan kawinkanlah orang-orang yang sendirian diantara kamu dan orangorang yang layak (berkawin) dari hamba-bamba sahayamu yang lelaki dan hamba sabayamu yang perempuan...".8

Secara arti istilah, ulama' fikih berbeda pendapat dalam mengartikan kata pernikhan. Dalam kitab Figh al- Mażabib alArba'ah disebutkan tentang pendapat empat mazhab fikih tentang definisi pernikahan sebagai berikut:

1. Mazhab Hanafi mendefinisikan nikah sebagai:

"Nikah itu adalah akad yang mengfaedahkan memiliki, bersenang-senang dengan sengaja".

${ }^{5}$ Wahbah Al- Zuhaily, Al- FIqh Al-Islämi wa Adillatubu, juz ke-VII(Damaskus: Dar Al- Fikr, 1997), 614.

${ }^{6}$ Abdurrahman Al-Jaziri, al-Figh 'ala Mażabib al-Arba'ah, jilid IV (Bairut: Dar alKutub al-Ilmiyah, 1990), 5.

7 Departemen Agama RI Al-Qur'an al-Karim dan Terjemahnya, (Kudus: Menara Kudus 1427 H), 36.

${ }^{8}$ Ibid, 282.

${ }_{9}$ Abdurrahman al-Jaziri, Fiqh al-Mażabib al-Arba'ah, 2. 
2. Mazhab Maliki mendefinisikan nikah sebagai:

"Nikah adalah akad pemberian hak milik atas manfaat alat kelamin dan seluruh badan istri."

3. Mazhab Syafi'i mendefinisikan nikah sebagai:

"Nikah adalah akad yang mengandung ketentuan hukum kebolehan waț'a dengan lafaz nikah atau tazwij atau yang semakna dengan keduanya."

4. Mazhab Hanbali mendefinisikan nikah sebagai:

"Nikah adalah akad dengan mempergunakan lafaz nikah atau tazwij guna membolehkan manfaat, bersenang-senang dengan wanita." 12

Perkawinan adalah merupakan tujuan syariat yang dibawa oleh Rasulullah SAW, yaitu penataan hal ihwal manusia dalam kehidupan duniawi dan ukhrawi. Dilihat dari tujuannya, perkawinan setidaknya mempunyai 5 (lima) tujuan seperti yang diungkapkan Zakiah Darajat dkk. dalam buku fikih munakahat karya H. M. A. Tihami, sebagai berikut: ${ }^{13}$

1. Mendapatkan dan melangsungkan keturunan.

2. Memenuhi hajat manusia menyalurkan syahwatnya dan menumpahkan kasih sayangnya.

3. Memenuhi panggilan agama, memelihara diri dari kejahatan dan kerusakan.

4. Menumbuhkan kesungguhan untuk bertanggung-jawab menerima hak serta kewajiban, juga bersungguh-sungguh untuk memperoleh harta kekayaan yang kekal.

5. Membangun rumah tangga untuk membentuk masyarakat yang tenteram atas dasar cinta dan kasih sayang.

Perkawinan juga bertujuan untuk menata keluarga sebagai subjek untuk membiasakan pengalaman-pengalaman ajaran

${ }^{10}$ Ibid.

${ }^{11}$ Ibid, 3 .

12 Ibid.,

${ }^{13}$ H.M.A. Tihami, Fikih Munakahat (Jakarta: Rajawali Press, 2010), 16.

\begin{tabular}{l|l}
$\mathbf{6}$ & $\begin{array}{l}\text { AL-HUKAMA } \\
\text { The Indonesian Journal of Islamic Family Law } \\
\text { Volume 07, Nomor 01, Juni } 2017\end{array}$
\end{tabular} 
keluarga. Fungsi keluarga adalah menjadi pelaksana pendidikan yang paling menentukan, karena keluarga merupakan salah satu lembaga pendidikan informal.Ibu-bapak yang dikenal pertama kali oleh putra-putrinya dengan segala perlakuan yang diterima dan dirasakannya, dapat menjadi dasar pertumbuhan pribadi sang putra-putri itu sendiri. Hal ini sebagaimana sabda Nabi Muhammad SAW:

"Tiada bayi yang dilabirkan melainkan labir di atas fitrah, maka ayah dan ibundanya yang menjadikan ia Yabudi, Nasrani atau Majusi."14

Perkawinan juga bertujuan untuk membentuk perjanjian antara seorang pria dan seorang wanita, yang mempunyai segi-segi perdata, diantaranya adalah: a) kesukarelaan, b) persetujuan kedua belah pihak, c) kebebasan memilih, d) kebutuhan pokok. ${ }^{15}$

Keluarga Islam terbentuk dalam keterpaduan antara ketenteraman (sakinah), penuh rasa cinta (mawaddah), dan kasih sayang (rabmab). Ia terdiri dari istri yang patuh dan setia, suami yang jujur dan tulus, ayah yang penuh kasih sayang dan ramah, ibu yang lemah lembut dan berperasaan halus, putra-putri yang patuh dan taat, serta kerabat yang saling membina silaturrahmi dan tolong-menolong. Hal ini bisa tercapai bila masing-masing anggota keluarga tersebut mengetahui dan menjalankan hak dan kewajibannya.16

Islam mengajarkan dan menganjurkan nikah karena akan berpengaruh baik bagi pelakunya sendiri, masyarakat dan seluruh umat manusia. Adapun hikmah pernikahan adalah: ${ }^{17}$

1. Jalan alami untuk menjaga pasangan suami-istri dari perbuatan haram.

2. Jalan terbaik untuk membuat anak menjadi mulia dari keterlantaran dan kehinaan.

14 Al-Bukhari, Șahīh al-Bukhāri(Beirut: Dar Al-Fikr,2003), jilid V, 143. Hadits nomor 1270.

${ }^{15}$ Muhammad Daud Ali, Hukum Islam di Indonesia: Pengantar Ilmu Hukum dan Tata Hukum Islam di Indonesia (Jakarta: RajaGrafindo Persada, 1993),124.

${ }^{16}$ Huzaimah Tahido Yanggo, Masail Fiqhiyyah: Kajian Hukum Islam Kontemporer (Bandung: Angkasa, 2005), 134.

17 Ibid, 
3. Dapat menjaga kelestarian populasi manusia dan menjaga garis keturunan.

4. Terbentuk sebuah keluarga yang merupakan dasar terbentuknya sebuah masyarakat.

5. Dapat menumbuhkan sikap saling menolong diantara individu, serta rasa ramah, cinta dan sayang.

6. Dapat memperkuat ikatan kekeluargaan dalam rangka mewujudkan kemaslahatan bersama.

Sedangkan menurut Kaelany H.D., ${ }^{18}$ terdapat hikmah di balik perikatan pernikahan antara pria dan wanita, antara lain: (1) hidup tentram dan sejahtera; (2) menghindari perzinahan; (3) memelihara keturunan; (4) memlihara wanita yang bersifat lemah; (5) menciptakan persaudaraan baru; dan (6) berhubungan dengan kewarisan.

Dengan adanya hikmah-hikmah perkawinan di atas, diharapkan dapat mendorong terwujudnya sebuah tatanan masyarakat dunia yang penuh dengan rasa saling menghormati, kasih-sayang, tolong-menolong dan saling menghargai antara yang satu dengan yang lainnya.

Salah satu fenomena yang mengemuka terkait pernikahan adalah poligami. Poligami berarti ikatan perkawinan yang salah satu pihak (suami) mengawini beberapa lebih dari satu istri dalam waktu yang bersamaan, bukan saat ijab qabul melainkan dalam menjalani hidup berkeluarga, sedangkan monogami berarti perkawinan yang hanya membolehkan suami mempunyai satu istri pada jangka waktu tertentu. ${ }^{19}$

Poligami adalah suatu bentuk perkawinan di mana seorang pria dalam waktu yang sama mempunyai istri lebih dari seorang wanita. Bentuk perkawinan pertama kali adalah monogami, sedangkan poligami datang belakangan sesuai dengan perkembangan akal pikiran manusia dari zaman ke zaman.

18 Titik Triwulan Tutik, Hukum Perdata dalam Sistem Hukum Nasional, (Jakarta: Prenada Media Group, 2010), 107-108.

19 Mahmudah,'Poligami Perspektif Hukum Islam dan Hukum Positif', dalam https://www.academia.edu/9107918/Poligami dalam Perspektif Hukum Isla $\mathrm{m}$ dan Hukum Positif?auto=download diakses pada tanggal 16 November 2016.

$8 \begin{aligned} & \text { AL-HUKAMA } \\ & \text { The Indonesian Journal of Islamic Family Law } \\ & \text { Volume 07, Nomor 01, Juni } 2017\end{aligned}$ 
Poligami merupakan salah satu persoalan yang dilontarkan oleh orang-orang yang memfitnah Islam dan seolah-olah memperlihatkan semangat pembelaan terhadap hak-hak perempuan. Poligami dalam Islam merupakan tema besar bagi mereka.Mereka menganggap kondisi perempuan dalam masyarakat Islam sangat memprihatinkan dan dalam kesulitan, karena tidak adanya persamaan antara laki-laki dan perempuan. ${ }^{20}$ footnote

Sebagaimana dikemukakan oleh banyak penulis, bahwa poligami itu berasal dari bahasa Yunani, kata ini merupakan penggalan kata Poli atau Polus yang artinya banyak, dan kata Gamein atau Gamos yang berarti kawin atau perkawinan. Jika kedua kata di atas digabungkan,maka arti poligami adalah perkawinan banyak dan bisa jadi dalam jumlah yang tidak terbatas. ${ }^{21}$

Namun dalam Islam, poligami mempunyai arti perkawinan yang lebih dari satu dengan batasan. Umumnya dibolehkan hanya sampai empat wanita saja.

\section{Poligami Perspektif Hukum Islam, UU No. 1 Tahun 1974, dan KHI}

Dalam wacana hukum Islam, poligami adalah isu yang sensi dan seksi. Sensitifitas poligami terutama berkisar pada keadilan gender vis a vis sakralitas nas. Deskripsi praktek poligami yang dihasilkan dari pemahaman terhadap nas seringkali menghasilkan konsep poligami yang tak berkeadilan; relasi gender yang timpang, mengukuhkan superioritas laki-laki terhadap perempuan. Di lain pihak, keyakinan atas nama firman Allah mengaharuskan pembacanya untuk memposisikan nas sebagai teks yang memiliki kebenaran absolut dan berkeadilan. ${ }^{22}$

Keseksian isu poligami dibuktikan dengan keikutsertaan pemikir muslim dari masa ke masa; dari yang bersifat konstruktif, rekonstruktif, maupun dekonstruktif. Para pemikir klasik umum takluk di bawah kuasa teks ayat dan hanya berupaya mencari alasan pendukung serta hikmah dari penshari'atan poligami. Al-Qurtubi

\footnotetext{
${ }^{20}$ Ibid,

${ }^{21}$ Ibid,

22 Syamsuri, "Poligami dalam Fiqh Mar'ah Perspektif Muhammad Sahrur", (Makalah Program Doktor-Pascasarjana UIN Sunan Ampel, Surabaya, 2016), 1.
} 
misalnya, ketika mengelaborasi empat belas poin penafsirannya terhadap ayat poligami justru mengarahkan kajiannya kepada kesimpulan bolehnya poligami sebagaimana bunyi ayat. ${ }^{23}$ Pemikir lain semisal al-Tabari yang melakukan kajian ayat poligami dengan pendekatan semantik dan riwayah juga mengahasilkan kesimpulan yang sama. Dalam komentarnya terhadap pendapat ulama' klasik mengenai poligami, Wahbah al-Zuhaili menyimpulkan bahwa mayoritas ahli hukum dari kalangan sunni memiliki persepktif yang sama tentang poligami dengan jumlah maksimal empat (4) istri dari wanita merdeka. ${ }^{24}$

Dengan demikian, poligami merupakan salah satu persoalan dalam perkawinan yang paling banyak dibicarakan sekaligus kontroversial. Satu sisi poligami ditolak dengan berbagai macam argumentasi, baik yang bersifat normatif, psikologis, bahkan selalu dikaitkan dengan ketidak adilan gender-sebagaimana diungkapkan aktivis gender atau pegiat perempuan,bahkan penulis Barat sering mengklaim bahwa poligami adalah bukti ajaran Islam bidang perkawinan sangat diskriminatif terhadap perempuan,pada sisi lain, poligami dikampanyekan karena dianggap sebagai salah satu alternatif untuk menyelesaikan fenomena selingkuh dan prostitusi.

Berangkat dari pandangan tersebut, penulis berupaya melihat isu poligami tersebut dengan beragam sudut pandang, yaitu hukum Islam, UU No. 1 Tahun 1974, dan KHI:

1. Tinjauan Hukum Islam

Poligami memiliki akar sejarah yang cukup panjang, sepanjang sejarah peradaban manusia itu sendiri. Sebelum Islam datang ke Jazirah Arab, poligami merupakan sesuatu yang sudah mentradisi bagi masyarakat Arab. Poligami masa itu dapat disebut poligami tak terbatas. Lebih dari itu tidak ada gagasan keadilan di antara para istri. Suamilah yang menentukan sepenuhnya siapa yang paling ia sukai dan siapa yang ia pilih untuk dimiliki secara tidak terbatas. Para istri harus menerima 
takdir mereka tanpa ada usaha untuk memperoleh keadilan.

Kehadiran Islam dengan ayat-ayat poligaminya, meskipun tidak menghapus praktik ini, membatasi kebolehan poligami hanya sampai empat orang istri dengan syarat-syarat yang ketat pula seperti keharusan berlaku adil di antara para istri. Syaratsyarat ini ditemukan di dalam surah an-Nisa': 3 dan an-Nisa': 129.

Dan jika kalian kbawatir tidak akan dapat berlaku adil terhadap bakhak perempuan yatim (bilamana kalian menikabinya), maka nikabilah wanita-wanita lain yang kalian senangi: dua, tiga, atau empat. Kemudian jika kalian khawatir tidak dapat berlaku adil maka nikeabilah seorang wanita saja atau budak-budak perempuan yang kalian miliki. Yang demikian itu lebih dekat untuk kalian tidak berlaku aniaya."(AnNisa : 3)

Selanjutnya pada surah yang sama ayat 129 Allah berfirman yang artinya:

"Dan kamu sekali-kali tidak akan dapat berlaku adil di antara isteriisteri(mu), walaupun kamu sangat ingin berbuat demikian, karena itu janganlah kamu terlalu cenderung (kepada yang kamu cintai), sehingga kamu biarkan yang lain terkatung-katung. Dan jika kamu mengadakan perbaikean dan memelihara diri (dari kecurangan), maka sesunggubnya Allab Maha Pengampun lagi Maba Penyayang."(An-Nisa': 129)

Dalam penafsiran Asghar-sebagaimana dikutip Amir dan Azahri, ${ }^{25}$ dalam bukunya-sebenarnya dua ayat di atas menjelaskan betapa al-Qur'an begitu berat untuk menerima institusi poligami, tetapi hal itu tidak bisa diterima dalam situasi yang ada, maka al-Qur'an membolehkan laki-laki kawin hingga empat orang istri, dengan syarat harus adil. Dengan mengutip al-Tabari, menurut Asghar, inti ayat di atas sebenarnya bukan pada kebolehan poligami, tetapi bagaimana berlaku adil terhadap anak yatim, terlebih lagi ketika mengawini mereka. ${ }^{26}$

Berbeda dengan pandangan fiqh yang lain, poligami sebenarnya tidak lagi menjadi persoalan. Tidak terlalu

${ }^{25}$ Lihat Amir Nuruddin dan Azhari Akmal Taringan, Hukum Perdata Islam di Indonesia,(Jakarta: Prenada Media,2004), 158.

${ }^{26}$ Ibid, 
berlebihan jika dikatakan, bahwa ulama sepakat tentang kebolehan poligami, kendatipun dengan persyaratan yang bermacam-macam. Al-Sarakhsi menyatakan kebolehan poligami dan mensyaratkan pelakunya harus berlaku adil. ${ }^{27}$ Al-Kasani menyatakan lelaki yang berpoligami wajib berlaku adil terhadap istri-istrinya. ${ }^{28} \mathrm{Al}-S y a f i$ 'i juga mensyaratkan keadilan di antara para istri, dan menurutnya keadilan ini hanya menyangkut urusan fisik semisal mengunjungi istri di malam atau di siang hari. $^{29}$

Manakala disederhanakan, pandangan normatif al-Qur'an yang selanjutnya diadopsi oleh ulama' fiqh, setidaknya menjelaskan dua persyaratan yang harus dimiliki suami. Pertama, seorang lelaki yang akan berpoligami harus memiliki kemampuan dana yang cukup untuk membiayai berbagai keperluan dengan bertambahnya istri yang dinikahi. Kedua, seorang lelaki harus memperlakukan semua istrinya dengan adil. Masing-masing istri harus diperlakukan sama dalam memenuhi hak perkawinan serta hak-hak lain.

Berkaitan dengan alasan-alasan darurat sehingga suami boleh poligami, setidaknya ada delapan alasan yang bisa dikemukakan di sini. (1) istri mengidap suatu penyakit berbahaya yang sulit disembuhkan. (2) istri terbukti mandul dan dipastikan secara medis tidak bisa melahirkan. (3) istri sakit ingatan. (4) istri lanjut usia sehingga tidak dapat memenuhi kewajiban sebagai istri. (5) istri memiliki sifat buruk. (6) istri minggat dari rumah. (7) ketika terjadi ledakan perempuan dengan sebab perang/meningkatnya jumlah penduduk perempuan di suatu daerah. (8) kebutuhan suami beristri lebih dari satu, dan jika tidak menimbulkan bahaya dalam kehidupan dan pekerjaannya. ${ }^{30}$

Syarat-syarat di atas sangat longgar dan memberikan keleluasaan bagi suami untuk memutuskan, apakah ia akan

${ }^{27}$ Ibid,

${ }^{28}$ Ibid,

${ }^{29} \mathrm{Ibid}$,

${ }^{30}$ Ibid, 159 
melakukan poligami atau tidak. Titik tekannya adalah pada pihak suami, di mana hal ini dikritik oleh para feminis muslim. Memang dalam pandangan fuqaha, kebolehan poligami dipandang selesai. Beberapa syarat yang melekat pada suami diupayakan untuk diringankan bobotnya. Seperti yang dijelaskan penulis-penulis hukum Islam, syarat adil yang sejatinya mencakup fisik dan non fisik, diturunkan kadarnya menjadi keadilan fisik atau material belaka. Lebih dari itu, para ulama juga mencoba untuk menggali hikmah-hikmah yang tujuannya adalah untuk melakukan rasionalisasi terhadap praktik poligami.

Setidaknya, ada tiga hikmah dari praktik poligami. Pertama, kebolehan poligami yang dibatasi sampai empat orang, hal ini menunjukkan empat mata pencaharian laki-laki; pemerintahan, perdagangan, pertanian, dan industri. Kedua, bagi seorang suami yang memiliki empat orang istri berarti ia memiliki waktu senggang tiga hari dan ini merupakan waktu yang cukup untuk mencurahkan kasih sayang. ${ }^{31}$

Namun, hikmah tersebut bisa disanggah dengan empat dampak negatif poligami. Pertama, poligami dapat menimbulkan kecemburuan di antara para istri. Kedua, menimbulkan kekhawatiran istri kalau-kalau suami tidak bisa bersikap bijaksana dan adil. Ketiga, anak-anak yang dilahirkan dari ibu yang berlainan sangat rawan untuk terjadi perkelahian, permusuhan, dan saling cemburu. Keempat, kekacauan dalam bidang ekonomi, bisa saja pada awalnya suami memiliki kemampuan untuk poligami, namun bukan mustahil suatu saat akan mengalami kebangkrutan, maka yang akan menjadi korban akan lebih banyak. ${ }^{32}$

2. Tinjauan Undang-Undang No. 1 Tahun 1974 tentang Perkawinan

Meskipun Undang-Undang No. 1 Tahun 1974 tentang Perkawinan menganut asas monogami, seperti yang tertuang dalam pasal 3 yang menyatakan, seorang pria banya boleh mempunyai

31 Ibid, 160
${ }^{32}$ Ibid, 161. 
seorang istri dan seorang wanita hanya boleh mempunyai seorang suami, ${ }^{33}$ namun pada bagian yang lain dinyatakan bahwa dalam keadaan tertentu poligami dibenarkan. Klausul kebolehan poligami di dalam Undang-Undang No. 1 Tahun 1974 tentang Perkawinan sebenarnya hanyalah pengecualian dan untuk itu pasal-pasalnya mencantumkan alasan-alasan yang membolehkan tersebut.

Dalam pasal 4 Undang-Undang No. 1 Tahun 1974 tentang Perkawinan dinyatakan: seorang suami yang akan beristri lebih dari seorang apabilaz4:

1. Istri tidak dapat menjalankan kewajibannya sebagai istri;

2. Istri mendapat cacat badan atau penyakit yang tidak dapat disembuhkan;

3. Istri tidak dapat melahirkan keturunan.

Dengan adanya pasal-pasal yang membolehkan untuk berpoligami, kendatipun dengan alasan-alasan tertentu, jelaslah bahwa asas yang dianut undang-undang perkawinan sebenarnya bukan asas monogami mutlak, melainkan disebut asas monogami terbuka, atau dengan bahasa lain juga bisa dinamakan dengan asas monogami inklusif. Poligami ditempatkan pada status hukum darurat (emergency law), ${ }^{35}$ atau dalam keadaan yang luar biasa (extra ordinary circumstance). Di samping itu, lembaga poligami tidak semata-mata kewenangan

${ }^{33}$ Undang-Undang Perkawinan di Indonesia, (Surabaya: Arkola, tt), 6.

${ }^{34}$ Ibid, 6.

${ }^{35}$ Rasulullah menegaskan bahwa ajaran Islam menegasikan segala macam bentuk destruktif. Dan penegasian ini adalah suatu manfaat. Rasulullah bersabda:

Dan dalam hadis Amr bin Yahya dari ayahnya dari Nabi saw.merupakan hadis mursal "Tidak ada perbuatan destruktif dalam agama, terhadap diri sendiri dan orang lain" dan diriwayatkan secara maushul dengan menyebutkan Abi Sa’id didalamnya.Lihat Al-Baihaqi, al-Sunan al-Saghir li al-Baihaqi,Al-Maktabah alShamilah (CD-Rom: Al-Maktabah Al-Syamilah, Digital, tt.), jilid IV, 459. Dalam kitab al-ashbah wa al-nazäir dan kitab I⿳亠口冋h al-Qawäid al-Fiqhiyah, karya Abdullah bin Sai'd Muhammad juga terdapat kaidah yang merupakan penalaran atau bentuk derivasi dari hadis tersebut, yaitu:

Suatu bencana atau kemadlaratan itu dihilangkan. lihat Abdullah bin Sai'd Muhammad 'Ubbadi al-Lahji, I⿳̣̄ăh al-Qawäid al-Fiqhiyah (Surabaya: alHidayah,tt.), 42. Lihat Al-Suyuthi,al-Ashbah wa al-nazäir,(Beirut-Lebanon: Dar alKutub al-Ilmiah,2001),Juz I,165. 
penuh suami, tetapi atas dasar izin dari hakim (pengadilan). Oleh sebab itu, pada pasal 3 ayat 2 ada pernyataan:Pengadilan dapat member izin kepada seorang suami untuk beristri lebih dari seorang apabila dikehendaki oleh pihak-pihak yang bersangkutan. 36

Dengan ayat tersebut, jelas sekali Undang-Undang No. 1 Tahun 1974 tentang Perkawinan telah melibatkan Pengadilan Agama sebagai institusi yang cukup penting untuk mengabsahkan kebolehan poligami bagi seorang, sesuatu yang tidak ada preseden historisnya di dalam kitab fiqh klasik.

Berkenaan dengan pasal 4 di atas setidaknya menunjukkan ada tiga alasan yang dijadikan dasar mengajukan permohonan poligami. Pertama, istri tidak dapat menjalankan kewajibannya sebagai istri. Kedua, istri mendapat cacat badan atau penyakit yang tidak dapat disembuhkan (menurut Dokter). Ketiga, tidak dapat melahirkan keturunan.

Tampaknya, alasan-alasan ini bernuansa fisik kecuali alasan yang ketiga. Terkesan karena seorang suami tidak memperoleh kepuasan yang maksimal dari istrinya, maka alternatifnya adalah poligami. Namun demikian ternyata undang-undang perwakinan juga memuat syarat-syarat untuk kebolehan poligami. Seperti yang tertuang dalam pasal 5 ayat 1 Undang-Undang No. 1 Tahun 1974 tentang Perkawinan, ${ }^{37}$ syarat-syarat yang dipenuhi bagi seorang suami yang ingin melakukan poligami ialah:

1. Adanya persetujuan dari istri/istri-istri;

2. Adanya kepastian bahwa suami mampu menjamin keperluan hidup istri-istri dan anak-anak mereka;

3. Adanya jaminan bahwa suami akan berlaku adil terhadap istri dan anak-anak mereka.

Perbedaan persyaratan yang ada di pasal 4 dan 5 adalah: pada pasal 4 disebut dengan persyaratan alternatif yang artinya salah satu harus ada untuk dapat mengajukan permohonan poligami. Sedangkan pasal 5 adalah persyaratan kumulatif yakni seluruhnya harus dapat dipenuhi suami yang akan melakukan

36 Undang-Undang Perkawinan di Indonesia, (Surabaya: Arkola, tt), 6.

${ }^{37}$ Undang-Undang Perkawinan di Indonesia, (Surabaya: Arkola, tt), 6-7. 
poligami.

Dalam pasal 5 ayat 2 dijelaskan, bahwa persetujuan yang dimaksud pada ayat (1) huruf a pasal ini tidak dapat diperlukan bagi seorang suami, apabila istri-istrinya tidak mungkin dimintai persetujuannya dan tidak dapat menjadi pihak dalam perjanjian, atau apabila tidak ada kabar dari istrinya selama sekurangkurangnya 2 (dua) tahun, atau karena sebab-sebab lainnya yang perlu mendapat penilaian dari hakim pengadilan.

Dengan demikian, izin dari Pengadilan Agama tampaknya menjadi sangat menentukan dan signifikan, dari sini pula dijelaskan bahwa pegawai pencatat dilarang untuk melakukan pencatatan perkawinan seorang suami yang akan beristri lebih dari seorang sebelum adanya izin Pengadilan.

Selanjutnya untuk tinjauan KHI sebagaimana akan dijelaskan dalam tulisan ini, tampaknya tidak jauh berbeda seperti keterangan dalam Undang-Undang Perkawinan terkait masalah poligami.

\section{Tinjauan KHI}

$\mathrm{KHI}^{38}$ memuat masalah poligami ini pada bagian IX dengan judul, Beristri lebih dari satu orang yang diungkap dari pasal 55 sampai 59. Pada pasal 55 dinyatakan: ${ }^{39}$

a. Beristri lebih dari satu orang pada waktu bersamaan, terbatas hanya sampai empat orang istri;

b. Syarat utama beristri lebih dari satu orang, suami harus

\footnotetext{
${ }^{38}$ Kompilasi hukum Islam merupakan salah satu wujud hasil kerjasama berpikir (ijtihad) yang baik antara tokoh-tokoh Islam yang ada di berbagai wilayah hukum, khususnya di wilayah eksekutif (Departemen Agama-Menteri Agama) di peradilan (Mahkamah Agung), di perguruan tinggi (IAIN, UI), dan di masyarakat (Kiai, ulama). Model kerjasama seperti yang terjadi dalam proses pembentukan kompilasi hukum Islam tersebut kiranya dapat dijadikan tonggak sejarah sekaligus pengalaman berharga bagi upaya pembinaan dan pengembangan hukum Islam di Indonesia di masa-masa mendatang, baik yang dilakukan melalui jalur legislasi maupun non legislasi. Lihat Warkum Sumitro, Perkembangan Hukum Islam Di Tengab Dinamika Sosial Politik Di Indonesia, (Malang: Bayumedia Publishing, 2005), 214.

39 Kompilasi Hukum Islam, dicetak bersama Undang-Undang Perkawinan di Indonesia, (Surabaya: Arkola, tt), 196.
} 
mampu berlaku adil terhadap istri-istri dan anak-anaknya;

c. Apabila syarat utama yang disebut pada ayat (2) tidak mungkin dipenuhi, suami dilarang beristri lebih dari satu orang.

Lebih lanjut dalam KHI pasal 56 dijelaskan: ${ }^{40}$

a. Suami yang hendak beristri lebih dari satu orang harus mendapat izin dari Pengadilan Agama;

b. Pengajuan permohonan izin dimaksudkan pada ayat 1 dilakukan menurut tata cara sebagaimana diatur dalam Bab VIII PP No. 9 Tahun 1975;

c. Perkawinan yang dilakukan dengan istri kedua, ketiga, atau keempat tanpa izin dari Pengadilan Agama, tidak mempunyai kekuatan hukum.

Dari pasal-pasal di atas, KHI sepertinya tidak tidak berbeda semangat fiqhnyadengan Undang-Undang No. 1 Tahun 1974 tentang Perkawinan. Meskipun pada dasarnya Undang-Undang No. 1 Tahun 1974 tentang Perkawinan dan KHI menganut prinsip monogami, tetapi sebenarnya peluang yang diberikan untuk poligami juga terbuka lebar. Dikatakan demikian, karena kontribusi Undang-Undang No. 1 Tahun 1974 tentang Perkawinan dan KHI hanya sebatas tata cara prosedur permohonan poligami.

Pada pasal 57 dalam Kompilasi Hukum Islam, dijelaskan: ${ }^{41}$

Pengadilan Agama hanya member izin kepada suami yang akan beristri lebih dari seorang apabila:

a. Istri tidak dapat menjalankan kewajiban sebagai istri;

b. Istri mendapat cacat badan atau penyakit yang tidak dapat disembuhkan;

c. Istri tidak dapat melahirkan keturunan.

Tampak pada pasal 57 KHI di atas, Pengadilan Agama hanya memberikan izin kepada suami yang akan beristri lebih

${ }^{40}$ Ibid, 196.

${ }^{41}$ Ibid, 196-197. 
dari seorang apabila terdapat alasan-alasan sebagaimana disebut dalam pasal 4 Undang-Undang No. 1 Tahun 1974 tentang Perkawinan. Pada dasarnya pengadilan dapat member izin kepada seorang suami untuk beristri lebih dari seorang apabila dikehendaki oleh pihak-pihak yang bersangkutan.

Selanjutnya pada pasal 59 juga digambarkan betapa besarnya wewenang Pengadilan Agama dalam memberikan izin sehingga bagi istri yang tidak mau memberikan persetujuan kepada suaminya untuk berpoligami, persetujuan itu dapat diambil alih oleh Pengadilan Agama. Lebih lengkapnya bunyi pasal tersebut sebagai berikut: ${ }^{42}$

"Dalam hal istri tidak mau memberikan persetujuan, dan permohonan izin untuk beristri lebih dari satu orang berdasarkan atas salah alasan yang diatur dalam pasal 55 ayat (2) dan 57, Pengadilan Agama dapat menetapkan tentang pemberian izin setelah memeriksa dan mendengar istri yang bersangkutan di Persidangan Pengadilan Agama, dan terhadap penetapan ini istri atau suami dapat mengajukan banding atau kasasi".

Masalah enggannya istri memberikan persetujuan dapat saja terjadi, walaupun ada alasan yang digunakan suami seperti salah satu alasan yang terdapat pada pasal 57. Namun alasan tersebut tidak jelas. Misalnya, tuduhan suami bahwa istrinya tidak dapat menjalankan kewajiban sebagai seorang istri, si istri dapat menyangkal bahwa ia telah melaksanakan tugas dengan baik. Akibat tidak ada ukuran, perdebatan bisa terjadi dan istri tetap tidak mau memberikan persetujuannya. Dalam kasus ini, Pengadilan Agama dapat memberi penetapan izin poligami tersebut. Tampak sekali posisi wanita sangat lemah.

Meskipun demikian, terlepas dari kritik yang muncul terkait dengan beberapa persoalan poligami, dari penjelasan di atas dapat disimpulkan bahwa perundang-undangan perkawinan Indonesia tentang poligami sebenarnya telah berusaha mengatur agar laki-laki yang melakukan poligami adalah laki-laki yang

${ }^{42}$ Ibid, 
benar-benar: (1) mampu secara ekonomi menghidupi dan mencukupi seluruh kebutuhan (sandang-pangan-papan) keluarga (istri-istri dan anak-anak), serta (2) mampu berlaku adil terhadap istri-istrinya sehingga istri-istri dan anak-anak dari suami poligami tidak disia-siakan. Demikian juga perundangundangan Indonesia terlihat berupaya menghargai istri sebagai pasangan hidup suami. Tebukti, bagi suami yang akan melaksanakan poligami, suami harus terlebih dahulu mendapatkan persetujuan para istri.

Pada aspek yang lain, peranan Pengadilan Agama untuk mengabsahkan praktik poligami menjadi sangat menentukan bahkan dapat dikatakan satu-satunya lembaga yang memiliki otoritas untuk mengizinkan poligami.

\section{Analisis Fenomena Poligami: Antara Solusi Sosial dan Wisata Seksual}

Berpangkal tolak dari praktik poligami yang terjadi di masyarakat, penulis berkeinginan untuk mengkaji dan merelevansikan hal tersebut dengan pendekatan fenomenologi (phenomenological sociology). Alfred Schutz sebagai salah seorang tokoh teori ini bertolak dari pandangan Weber yang berpendirian bahwa tindakan manusia menjadi suatu hubungan sosial bila manusia memberikan arti atau makna tertentu terhadap tindakan itu dan manusia lain memahami pula tindakannya itu sebagai sesuatu yang penuh arti. ${ }^{43}$ Pemahaman secara subyektif terhadap sesuatu tindakan sangat menentukan terhadap kelangsungan proses interaksi sosial, baik bagi aktor yang memberikan arti terhadap tindakannya sendiri, maupun bagi pihak lain yang akan

\footnotetext{
${ }^{43}$ Max Weber lahir di Erfurt, Jerman, 21 April 1864, berasal dari keluarga kelas menengah. Perbedaan penting antara kedua orang tuanya berpengaruh besar terhadap orientasi intelektual dan perkembangan psikologi Weber. Singkat kata, ayahnya adalah seorang birokrat yang kedudukan politiknya sangat penting, ia lebih menyukai kesenangan duniawi, tentunya dalam hal ini bertolak belakang dengan ibunya yang seorang Calvinis yang taat, wanita yang berupaya menjalani kehidupan prihatin (ascetis) tanpa kesenangan yang sangat menjadi dambaan suaminya. Lihat George Ritzer-Douglas J. Goodman, Teori Sosiologi Modern, (Jakarta: Prenada Media-Kencana, 2005), 38.
} 
menerjemahkan dan memahaminya serta yang akan bereaksi atau bertindak sesuai dengan yang dimaksud oleh aktor.44

Praktik poligami yang dilakukan suami tanpa ada prinsip keadilan akan berdampak pada kerusakan. Asumsi ini mengindikasikan, bahwa keruskan harus dihindari, sehingga dengan jalan yang seperti itu, tercapai kebahagiaan yang hakiki. ${ }^{45}$ Tindakan manusia yang melakukan poligami dan ia bisa adil, atau ia tidak melakukan poligami dengan alasan takut tidak bisa berbuat adil, menurut hemat penulis merupakan tindakan yang bermakna. Begitu pula manusia yang melihat dan memahaminya juga memilki pandangan yang sama, bahwa apa yang dilakukan oleh aktor adalah tindakan yang bermakna. Dari sini munculah interaksi sosial yang berpangkal tolak dari pemahaman subyektif, dalam hal ini adalah tindakan manusia yang melakukan poligami dan ia bisa adil atau ia tidak melakukan poligami dengan alasan takut tidak bisa berbuat adil.

Berkaitan dengan prosedur poligami di mana suami harus mendapatkan izin dari pengadilan. Apakah izin pengadilan itu merupakan syarat sah perkwinan? Kalau "iya" maka hal tersebut (setidaknya dalam teori) bertentangan dengan pasal 2 ayat 1 yang tegas menyatakan bahwa perkawinan adalah sah, apabila dilakukan menurut hukum masing-masing agamanya. Dan dalam hubungan ini, hukum perkawinan Islam tradisional belum menentukan izin

44 George Ritzer, Sosiologi Ilmu Pengetahuan Berparadigma Ganda, Jakarta: Rajagrafindo Persada, 2009), 59.

45 Allah berfirman dalam al-Qur'an, di mana Nabi diutus untuk membawa rahmat bagi semesta alam. Adapun manusia diperintah mengimitasi sifat Nabi tersebut, dengan harapan terwujud tatanan yang menyejukkan dalam setiap sendi kehidupan. Ayat yang berkaitan dengan itu adalah:

Dan Tiadalah Kami mengutus kamu, melainkan untuk (menjadi) rahmat bagi semesta alam.(al-Anbiya' 107). Lihat Departemen Agama, Al-Qur'an al-Karim dan Terjemahnya RI, (Kudus: Menara Kudus 1427 H), 331.

Shari'ah berdiri tegak dengan klaim tujuan yang universal, yaitu: kebahagiaan individu dan golongan, penjagaan terhadap aturan-aturan, menghiasi dunia dengan segala hal yang bisa menyampaikan pada tujuan shariah sehingga terwujud kesempurnaan, kebaikan dan peradaban. Dari sini, tampaklah bahwa tujuan dakwah Islam ialah rahmah bagi manusia. Lihat Wahbah al-Zuhaily, Nazariyah al- Darürah al-Shar'iyah, (Beirut: Muasasah al-Risalah, tt), 49. 
pengadilan itu sebagai rukun nikah yang menentukan sah tidaknya suatu perkawinan. Dalam rangka mengatasi hal ini, izin pengadilan agama paling tidak, hanya sebatas sebagai syarat yang harus dipenuhi dalam upaya melindungi kaum wanita dan anak-anak dari kesewenang-wenangan.

Selanjutnya berkenaan dengan syarat berlaku adil, hal ini sering menjadi perdebatan yang panjang, tidak saja di kalangan ahli hukum tetapi juga di masyarakat. Apa yang sebenarnya disebut dengan adil dan dalam hal apa suami harus berlaku adil.Kebanyakan dari ulama fiqh mengaklaim bahwa yang dimaksud keadilan di sini adalah dari aspek material, semisal persamaan dalam hal tempat tinggal, pakaian, makanan, minuman, dan segala hal yang berbentuk material. Hal ini sebagaimana diungkapkan oleh al-Zahabi. ${ }^{46}$ Ini artinya ulama fiqh lebih cenderung memahami keadilan di sini secara kuantitatif yang bisa diukur dengan angka-angka, padahal ada pandangan lain yang mengatakan, bahwa keadilan yang disyaratkan dalam al-Qur'an adalah keadilan yang bersifat kualitatif seperti kasih-sayang, cinta, perhatian yang semuanya tidak bisa diukur dengan angka-angka. ${ }^{47}$

Lalu, apakah keadilan kualitatif ini mungkin diwujudkan dan bagaimana pula cara mengukurnya. Sebagian besar ahli hukum Islam menyadari bahwa keadilan kualitatif ini sesuatu yang sangat absurd (mustahil) bisa diwujudkan. Praktik ini boleh dilakukan dalam kondisi darurat, semisal kondisi istri yang cacat fisik, tidak bisa melahirkan, maupun jumlah perempuan yang meningkat tajam, jika dibandingkan dengan laki-laki. Nah, poligami di sini muncul sebagai solusi sosial, namun apabila poligami hanya dijadikan sebagai perilaku wisata seksual, penulis rasa hal ini merupakan tindakan yang kurang bermakna, meskipun agama (sebagaimana keterangan dalam teks al-Qur'an) membolehkan.

Dengan demikian motivasi utama dari poligami adalah motivasi sosial untuk membantu para janda dengan anak-anaknya serta gadis-gadis yatim yang membutuhkan pertolongan, meskipun

46

Amir Nuruddin dan Azhari Akmal Taringan, Hukum Perdata Islam di Indonesia, 171.

${ }^{47}$ Ibid, 
tidak menutup kemungkinan ada motivasi lain, yaitu motivasi yang bersifat biologis.

Sebagaimana pendapat Mustaqim yang mengukuhkan pendapat Riffat Hasan, bahwa pentingnya seseorang memahami konsep poligami dalam Islam secara baik dan benar. ${ }^{48}$ Sebenarnya ide dasar poligami adalah untuk melindungi dan menyantuni para janda dan anak-anak yatim. Dengan bahasa lain, bahwa konsep poligami yang ditawarkan al-Qur'an sebenarnya bukan sematamata untuk memberikan kepuasan seksual bagi laki-laki dengan mengabaikan prinsip etis, akan tetapi lebih pada perlindungan, penyantunan para janda dan anak-anak yatim. Itu pun dilakukan dalam kondisi darurat, dan dengan syarat seorang suami harus dapat berlaku adil. Dengan demikian, Riffat_-sebagaimana dikutip oleh Mustaqim - cenderung memberikan syarat-syarat yang sangat ketat bagi pelaksanaan poligami.

Berbeda dengan pandangan Amina Wadud Muhsin, ia menyatakan, meskipun memiliki anak adalah hal yang alamiah, maka mengasuh anak-anak yatim yang terlantar adalah dibenarkan al-Qur'an, bukan dengan melakukan poligami. Selanjutnya ia juga beranggapan, bahwa poligami merupakan bukan tindakan Qur'ani. Oleh karena itu, orang yang melakukan poligami dengan argumentasi teks al-Qur'an, adalah usahanya untuk mendukung nafsu tak terkendali kaum pria; jika kebutuhan seksual seorang pria tidak dapat dipenuhi dengan seorang istri-selanjutnya ia memiliki lebih dari satu istri. Pandangan ini tentunya berbeda dengan pandangan ulama fiqh maupun mufasir klasik. ${ }^{49}$

48 Abdul Mustaqim, Paradigma Tafsir Feminis: Membaca Al-Qur'an dengan Optik Perempuan, (Yogjakarta: Logung Pustaka, 2008), 240.

49 Amina Wadud adalah salah satu tokoh feminis atau aktivis gender yang pernah menulis buku dengan judul Inside the Gender Jihad: Women's Reform in Islam, sebagaimana pada umumnya mufasir feminis, di mana dalam memahami hingga memperoleh kesimpulan makna suatu teks atau ayat, selalu berkaitan dengan tiga aspek: (1) dalam konteks apa ayat itu ditulis, jika dikaitkan dengan al-Qur'an, maka dalam konteks apakah ayat itu diturunkan, (2) bagaimana komposisi tata bahasa teks, (3) bagaimana keseluruhan teks atau pandangan hidupnya. Lihat Abdul Mustaqim, Paradigma Tafsir Feminis: Membaca Al-Qur'an dengan Optik Perempuan, 40. 


\section{Penutup}

Bagaimanapun, poligami tetap akan diperdebatkan. Sebenarnya masalahnya tidak terlalu berat dan tidak perlu menempatkannya sebagai sesuatu yang membahayakan bagi kehidupan perempuan sehingga harus ditolak secara a priori. Poligami merupakan shari'ah agama yang keberadaannya jelas di dalam al-Qur'an, terlepas bagaimana ayat tersebut diterapkan. Permasalahannya adalah dalam kondisi yang bagaimana dan oleh siapa shari'ah poligami ini bisa dilaksanakan.

Manakala seseorang memiliki kesanggupan, kemudian ia beristri lebih dari satu orang, dan hal ini merupakan kebutuhan dirinya sehingga ia tetap dapat memelihara muru'ah, serta ia bisa berbuat adil, maka ia boleh melakukan poligami. Sebaliknya orang yang tidak memiliki syarat-syarat yang pantas, maka poligami merupakan sesuatu yang harus dihindari, karena dengan jalur poligami, ia tidak akan mendapatkan kebahagiaan hakiki. Dengan demikian, dapat kita tarik benang merah, bahwa poligami merupakan sesuatu yang sangat pribadi dan kondisional. Adalah tidak tepat, manakala poligami digeneralisir, seakan-akan ia shari'ah yang berlaku umum dan dapat dilaksanakan oleh semua orang.

\section{Daftar Pustaka}

Beni Ahmad Saebani. Fiqh Munakhat, Bandung: Pustaka Setia,2009.

Baihaqi.(al) al-Sunan al-Saghir li al-Baihaqi,Al-Maktabah al-Shamilah, CD-Rom: Al-Maktabah Al-Syamilah, Digital, tt..

Bukhari.(al) Sabīh al-Bukhāri, Beirut: Dar Al-Fikr,2003.

Muhammad Daud Ali. Hukum Islam di Indonesia: Pengantar Ilmu Hukum dan Tata Hukum Islam di Indonesia, Jakarta: RajaGrafindo Persada, 1993.

Departemen Agama. Al-Qur'an al-Karim dan Terjemahnya RI, Kudus: Menara Kudus $1427 \mathrm{H}$.

Abdurrahman Jaziri.(al) al-Figh 'ala Mażabib al-Arba'ah, jilid IV, Bairut: Dar al-Kutub al-Ilmiyah, 1990. 
Moh. Faizur Rohman \& Muhammad Solikhudin: Fenomena Poligami...

Kompilasi Hukum Islam, dicetak bersama Undang-Undang Perkawinan di Indonesia, Surabaya: Arkola, tt..

Khatib al-Syarbini, Syamsudin Muhammad ibn Muhammad,(al) Mughni al-Mubtäj, Bairut: Dar al-Kutub al-Islamiyah, 1994.

Mahmudah,"Poligami Perspektif Hukum Islam dan Hukum Positif", dalam https://www.academia.edu/9107918/Poligami dalam_Per spektif Hukum Islam dan Hukum Positif?auto=downlo ad diakses pada tanggal 16 November 2016.

Mustaqim, Abdul, Paradigma Tafsir Feminis: Membaca Al-Qur'an dengan Optik Perempuan, (Yogjakarta: Logung Pustaka, 2008)

Muhammad 'Ubbadi al-Lahji, Abdullah bin Sai'd,Iḍāh al-Qawàid alFiqhiyah, Surabaya: al-Hidayah,tt..

Amir Nuruddin, dan Azhari Akmal Taringan.Hukum Perdata Islam di Indonesia, Jakarta: Prenda Media,2004.

Abdul Rahman Ghozali. Fiqh Munakahat, Cet. Ke-III, Jakarta: Kencana,2008.

George Ritzer dan Douglas J. Goodman.Teori Sosiologi Modern, (Jakarta: Prenada Media-Kencana, 2005)

.Sosiologi Ilmu Pengetahuan Berparadigma Ganda,Jakarta: Rajagrafindo Persada, 2009.

Warkum Sumitro.Perkembangan Hukum Islam Di Tengab Dinamika Sosial Politik Di Indonesia, Malang: Bayumedia Publishing, 2005.

Syafi'i al-Azhary, Abdullah ibn Hijazi ibn Ibrahim,(al) Häsyiah alSyarqāwī, Bairut: Dar al-Kutub al-Ilmiah,2005.

Suyuthi,(al), al-Ashbah wa al-nazäirr, Beirut-Lebanon: Dar al-Kutub al-Ilmiah,2001.

Syamsuri, "Poligami dalam Fiqh Mar'ah Perspektif Muhammad Sahrur", Makalah Program Doktor-Pascasarjana UIN Sunan Ampel, Surabaya, 2016. 
Moh. Faizur Rohman \& Muhammad Solikhudin: Fenomena Poligami...

Huzaimah Tahido Yanggo.Masail Fiqhiyyah: Kajian Hukum Islam Kontemporer, Bandung: Angkasa, 2005.

H.M.A. Tihami.Fikih Munakahat, Jakarta: Rajawali Press, 2010.

Titik Triwulan Tutik.Hukum Perdata dalam Sistem Hukum Nasional, Jakarta: Prenada Media Group, 2010.

Undang-Undang Perkawinan di Indonesia, Surabaya: Arkola, tt..

Wahbah Zuhaily.(al) Al- Fiqh Al-Islämi wa Adillatubu, Damaskus: Dar Al- Fikr, 1997.

- Nazariyah al- Darürah al-Shariyah, Beirut: Muasasah alRisalah, tt.. 